\title{
ISOLASI DAN IDENTIFIKASI KAPANG DARI IKAN PINDANG
}

\section{Isolation and Identification of Fungi from Boiled Salted Fish}

\author{
Irma Hermana*, Arifah Kusmarwati, dan Yusma Yennie \\ Balai Besar Riset Pengolahan Produk dan Bioteknologi Kelautan dan Perikanan, \\ JI. KS Tubun Petamburan VI, Slipi, Jakarta, Indonesia \\ *Korespondensi Penulis: ihermana23@gmail.com
}

Diterima: 3 November 2017; Direvisi: 13 Februari 2018; Disetujui: 15 Maret 2018

\begin{abstract}
ABSTRAK
Penelitian ini bertujuan untuk mengetahui jenis-jenis kapang yang diisolasi dari produk ikan pindang. Pengambilan sampel dilakukan di enam lokasi, yaitu Jakarta, Bogor, Pelabuhan Ratu, Bandung, Cirebon, dan Semarang. Isolasi kapang dilakukan dengan metode pengenceran bertingkat, sedangkan identifikasi kapang dilakukan secara morfologi dan molekuler berdasarkan data sekuen nukleotida dari daerah ITS rDNA. Sebagai data dukung, terhadap ikan pindang juga dilakukan analisis kadar garam dan nilai aktivitas air $\left(a_{w}\right)$. Hasil analisis menunjukkan bahwa kadar garam sampel ikan pindang berkisar antara 1,20-7,78\% dengan $a_{w}, 0,91-0,98$. Sebanyak 119 isolat kapang berhasil diisolasi dari 30 sampel ikan pindang. Isolat-isolat tersebut termasuk ke dalam tujuh marga dan 16 spesies yaitu Aspergillus flavus, A. fumigatus, A. niger, A. ochraceus, A. oryzae, A. sydowii, A. terreus, Cladosporium allicinum, Eurotium chevalieri, Fusarium graminearum, F. cerealis, Loweporus sp., Penicillium citrinum, P. chermesinum, $P$. chrysogenum, dan Syncephalastrum racemosum. Terdapat enam jenis kapang yang dominan yaitu $P$. chermesinum (80\%), diikuti oleh P. citrinum (73\%), A. fumigatus (56,6\%), A. flavus (53,3\%), A. niger $(46,7 \%)$, dan E.chevalieri $(26,7 \%)$. Tidak ada hubungan antara jenis kapang yang tumbuh dengan jenis ikan pindang, nilai $a_{w}$ maupun kadar garam; namun pertumbuhan kapang berkaitan dengan kadar garam. Kadar garam ikan pindang yang lebih rendah menyebabkan pertumbuhan kapang yang lebih banyak.
\end{abstract}

KATA KUNCI: ikan pindang, kapang, Aspergillus, Penicillium, Eurotium

\section{ABSTRACT}

This study aimed to determine fungal species isolated from boiled salted fish. Sampling was conducted from six locations, i.e. Jakarta, Bogor, Pelabuhan Ratu, Bandung, Cirebon, and Semarang. Isolation of fungi was carried out by serial dilution method, and the fungal identification was conducted using combination of morphology and molecular analyses based on ITS rDNA sequence data. As the support data, salt content and water activity $\left(a_{w}\right)$ of boiled salted fish were examined. The result showed that salt content of boiled salted fish samples ranged from 1.20 to 7.78\% with $a_{w}$ of 0.91-0.98. A total of 119 isolates from 30 boiled salted fish samples were obtained. These isolates belong to seven genera and 16 species as follow: Aspergillus flavus, $\underline{A}$. fumigatus,

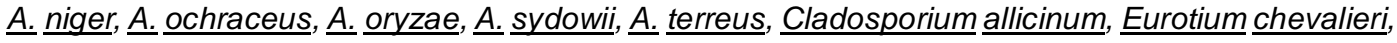
$\underline{\text { Fusarium graminearum, }} \underline{F}$. cerealis, Loweporus sp., Penicillium citrinum, $\underline{P}$ chermesinum, $\underline{P}$.

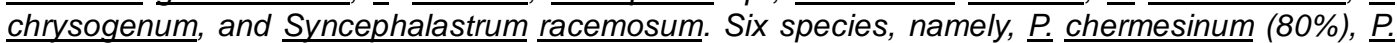

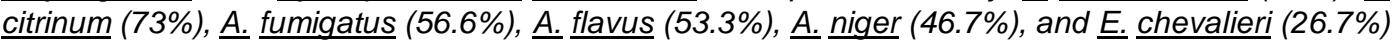
were determined as dominant species. There was no correlation between fungi species isolated and species of boiled salted fish, $a_{w}$ or salt content. However, lower salt content of boiled salted fish caused high growth of fungi.

\section{KEYWORDS: boiled salted fish, fungi, Aspergillus, Penicillium, Eurotium}

\section{PENDAHULUAN}

Ikan pindang merupakan salah satu produk olahan ikan tradisional yang sangat populer dan banyak disukai oleh masyarakat Indonesia (Ariyani \& Yennie, 2008). Produk ini diolah dengan cara kombinasi perebusan/pengukusan dan penggaraman dengan waktu tertentu. Terdapat tiga macam proses pemindangan, yaitu pemindangan air garam (naya), pemindangan garam (badeng/paso) dan pemindangan presto (Wibowo, 1996). Produsen terbesar ikan pindang di Indonesia adalah Pulau Jawa, sebesar 68\% 
(Anon., 2016) dengan Provinsi Jawa Barat merupakan pasar dan konsumsi terbesar untuk produk olahan pindang (Anon., 2012). Pengolahan ikan pindang di Indonesia sebagian besar belum menerapkan sanitasi dan higiene sehingga produk yang dihasilkan bermutu rendah (Thaheer, Hasibuan, \& Mumpuni, 2015) dan lebih mudah mengalami kerusakan, salah satunya disebabkan oleh pertumbuhan kapang (Ariyani \& Yennie, 2008). Akibat selanjutnya adalah ikan pindang mempunyai daya awet yang relatif pendek yaitu berkisar 1-3 hari (Irianto \& Pratiwi, 2009; Nasran, 1980 dalam Ariyani \& Yennie, 2008) atau 2-7 hari (Gopakumar, 1977 dalam Ariyani \& Yennie, 2008; Irianto \& Pratiwi, 2009).

Kapang merupakan mikroorganisme eukariotik, tidak berklorofil, memiliki hifa, dinding sel terdiri dari kitin atau selulosa, serta berkembang biak secara seksual dan aseksual (Gandjar, Samson, \& Vermeulen, 1999; Pitt \& Hocking, 2009; Rahayu, Kamil, Damara, \& Sidar, 2014). Kapang pada umumnya hidup secara aerob, tumbuh optimal pada kisaran suhu $25-30^{\circ} \mathrm{C}$ dan dapat tumbuh pada kisaran $\mathrm{pH}$ yang cukup luas yaitu 2,0-8,5 meskipun pada kenyataannya kapang lebih suka pada kondisi asam (Winarno, 1994 dalam Agustin 2016; Pitt \& Hocking, 2009). Kapang mampu tumbuh dengan baik pada kisaran $a_{w}$ 0,65-0,95 (Pitt \& Hocking, 2009; Rahayu et al., 2014) atau 0,60-0,70 (Rahayu \& Nurwitri, 2012; Winarno, 1992). Spora kapang berukuran kecil dan ringan sehingga dapat terhembus ke udara dan menyebar kemana-mana (Susilowati \& Listyawati, 2001). Ikan pindang yang umumnya memiliki $a_{w}>0,9$ memungkinkan dapat terkontaminasi oleh kapang, termasuk kapang penghasil toksin. Rahmadi dan Fleet (2008) melaporkan jenis-jenis kapang yang menghasilkan toksin antara lain adalah $A$. flavus, $A$. parasiticus, dan $A$. niger, sedangkan menurut Maryam (2007) kapang toksigenik yaitu Aspergillus sp. dan Fusarium sp.

Identifikasi kapang dapat dilakukan berdasarkan karakteristik morfologi makroskopis-mikroskopis seperti warna permukaan koloni, warna sebalik koloni, tekstur, dan diameter pertumbuhan koloni, serta bentuk konidia (Pitt \& Hocking, 2009; Yulneriwarni \& Noverita, 2014), namun cara ini hanya mampu mengidentifikasi kapang sampai pada tingkat genus. Saat ini, identifikasi kapang sampai dengan tingkat spesies umumnya dilakukan secara molekuler berdasarkan data sekuen nukleotida dari daerah internal transcribed spacer (ITS) yang merupakan daerah kandidat untuk barcoding kelompok kapang (Schoch et al., 2012). Identifikasi beberapa spesies di dalam kelompok kapang perusak makanan (food spoilage) seperti Aspergillus dan Fusarium harus dilakukan dengan menggunakan pendekatan multigen
(O'Donnell, Logan, \& Clayton, 2012; Samson et al., 2014).

Penelitian mengenai isolasi dan identifikasi kapang pada ikan pindang di Indonesia belum banyak dilakukan. Indriati, Supriadi, dan Salasa (2008) yang melakukan isolasi dan identifikasi pada pindang ikan tongkol memperoleh jenis-jenis kapang $A$. flavus, $A$. niger, $A$. ochraceus, P. chrysogenum, dan Rhyzopus oryzae. Beberapa di antaranya berpotensi menghasilkan toksin. Oleh karena itu, penelitian ini dilakukan untuk memperoleh informasi yang lebih lengkap mengenai diversitas jenis-jenis kapang yang tumbuh pada ikan pindang di beberapa lokasi di Indonesia.

\section{BAHAN DAN METODE}

\section{Bahan}

Bahan yang digunakan dalam penelitian ini adalah ikan pindang yang diperoleh dari Palabuhan Ratu, Bandung, Bogor, Cirebon, Semarang, dan Jakarta. Pemilihan lokasi ini didasarkan pada tingginya tingkat produksi dan konsumsi ikan pindang yang sebagian besar di Provinsi Jawa Barat, sehingga daerah ini merupakan pasar terbesar ikan pindang (Anon., 2012), sedangkan Semarang merupakan produsen bandeng presto terbesar (Chandra \& Setiawan, 2013).

\section{Metode}

\section{Sampling ikan Pindang}

Sebanyak 30 sampel ikan pindang dikumpulkan dari bulan April- Agustus 2015, dengan metode purposive random sampling (Nasution, 2003). Sampel diambil dari tempat pengolah dan pengecer (pasar) ikan pindang. Pengambilan sampel ikan pindang di tempat pengolah dilakukan segera setelah pindang matang, sedangkan sampel dari tempat pengecer (pasar) ikan pindang berumur satu hari. Jumlah dan jenis ikan sampel pindang dari setiap lokasi disajikan pada Tabel 1.

Sebanyak 500-1000 g dari masing-masing sampel dimasukkan ke dalam kantong plastik steril, kemudian diberi label. Selanjutnya sampel disimpan dalam wadah dan dibawa ke laboratorium untuk dianalisis, meliputi kadar garam (SNI, 1991) dan aktivitas air $\left(\mathrm{a}_{\mathrm{w}}\right)$ menggunakan aw meter (Novasina TH 500).

\section{Isolasi kapang}

Kapang diisolasi dari sampel ikan pindang dengan mengacu SNI 2009 menggunakan metode pengenceran bertingkat, kemudian disebarkan di atas medium Dichloran Rose Bengal Chlorampenicol (DRBC) Agar (Indriati et al., 2010; Pitt \& Hocking, 
Tabel 1. Jumlah dan jenis ikan sampel pindang dari setiap lokasi Table 1. Number and type of boiled salted fish at each location

\begin{tabular}{|c|c|c|c|c|}
\hline No & $\begin{array}{l}\text { Nama Ikan/ } \\
\text { Fish Name }\end{array}$ & $\begin{array}{l}\text { Lokasi Pengambilan } \\
\text { Sampel/Sampling } \\
\text { location }\end{array}$ & $\begin{array}{l}\text { Asal Sampel/ } \\
\text { Origin of sampel }\end{array}$ & $\begin{array}{l}\text { Kondisi Lingkungan/ } \\
\text { Environment conditions }\end{array}$ \\
\hline 1. & $\begin{array}{l}\text { Semar/Moon Fish (Mene } \\
\text { maculata) }\end{array}$ & P. Ratu & Pengolah 1/Processor 1 & $\begin{array}{l}\text { Tidak higienis, pengap, dekat dengan perumahan } \\
\text { penduduk dan penginapan/unhygienic, stuffy, } \\
\text { close to residential area and hotels }\end{array}$ \\
\hline 2. & $\begin{array}{l}\text { Tongkol/Mackerel Tuna } \\
\text { (Euthynnus affinis) }\end{array}$ & P. Ratu & Pengolah 1/ Processor 1 & $\begin{array}{l}\text { Tidak higienis, pengap, dekat dengan perumahan } \\
\text { penduduk dan penginapan/Unhygienic, stuffy, } \\
\text { close to residential area and hotels }\end{array}$ \\
\hline 3. & $\begin{array}{l}\text { Tongkol/Mackerel Tuna } \\
\text { (E. affinis) }\end{array}$ & P. Ratu & Pengecer1/Retailer 1 & $\begin{array}{l}\text { Dekat dengan Tempat Pelelangan Ikan/Close to } \\
\text { fishing port }\end{array}$ \\
\hline 4. & $\begin{array}{l}\text { Layang/Indian Scad } \\
\text { (Decapterus russelli) }\end{array}$ & P. Ratu & Pengecer 1/Retailer 1 & $\begin{array}{l}\text { Dekat dengan Tempat Pelelangan Ikan/Close to } \\
\text { fishing port }\end{array}$ \\
\hline 5. & $\begin{array}{l}\text { Tongkol/Mackerel Tuna } \\
\text { (E. affinis) }\end{array}$ & P. Ratu & Pengolah 2/ Processor 2 & $\begin{array}{l}\text { Tidak higienis, pengap, dekat dengan perumahan } \\
\text { penduduk/Unhygienic, stuffy, close to residential }\end{array}$ \\
\hline 6. & $\begin{array}{l}\text { Tongkol/ Mackerel Tuna } \\
\text { (E. affinis) }\end{array}$ & P. Ratu & Pengecer 2/Retailer 2 & $\begin{array}{l}\text { Dekat dengan pasar ikan dan jalan raya/Close to } \\
\text { fish market and highway }\end{array}$ \\
\hline 7. & $\begin{array}{l}\text { Tongkol/Mackerel Tuna } \\
\text { (E. affinis) }\end{array}$ & P. Ratu & Pengecer $3 /$ Retailer 3 & $\begin{array}{l}\text { Di pasar sayuran dekat penjual cabe, beras dan } \\
\text { kacang/in the fresh market, close to chili, rice and } \\
\text { beans retailers }\end{array}$ \\
\hline 8. & $\begin{array}{l}\text { Bandeng/Milk Fish } \\
\text { (Chanos chanos) }\end{array}$ & Semarang & Pengecer $1 /$ Retailer 1 & $\begin{array}{l}\text { Higienis, toko penjual oleh-oleh/Hygienic, gift } \\
\text { shop }\end{array}$ \\
\hline 9. & $\begin{array}{l}\text { Bandeng/Milk Fish (C. } \\
\text { chanos) }\end{array}$ & Semarang & Pengecer 2/Retailer 2 & $\begin{array}{l}\text { Dekat dengan penjual sayuran/Close to } \\
\text { vegetable shop }\end{array}$ \\
\hline 10. & $\begin{array}{l}\text { Bandeng/Milk Fish (C. } \\
\text { chanos) }\end{array}$ & Semarang & Pengolah 1/ Processor 1 & Higienis/Hygienic \\
\hline 11. & $\begin{array}{l}\text { Bandeng/Milk Fish (C. } \\
\text { chanos) }\end{array}$ & Semarang & Pengolah 2/ Processor 2 & $\begin{array}{l}\text { Dekat dengan rumah tinggal, bersih/Close to } \\
\text { residential areas, clean }\end{array}$ \\
\hline 12. & $\begin{array}{l}\text { Bandeng/Milk Fish ( } C \text {. } \\
\text { chanos) }\end{array}$ & Semarang & Pengecer $3 /$ Retailer 3 & $\begin{array}{l}\text { Dekat dengan penjual sayuran/Close to } \\
\text { vegetable retailer }\end{array}$ \\
\hline 13. & $\begin{array}{l}\text { Tongkol/ Mackerel Tuna } \\
\text { (E. affinis) }\end{array}$ & Bogor & Pengolah/ Processor & $\begin{array}{l}\text { Tidak higienis, dekat kandang ayam/Unhygienic, } \\
\text { close to chicken coop }\end{array}$ \\
\hline 14. & $\begin{array}{l}\text { Tongkol/Mackerel Tuna } \\
\text { (E. affinis) }\end{array}$ & Bogor & Pengecer/Retailer & $\begin{array}{l}\text { Dekat penjual sayuran, cabe ,beras dan } \\
\text { kacang/Close to vegetable, chili, rice and bean } \\
\text { retailer }\end{array}$ \\
\hline 15. & $\begin{array}{l}\text { Semar/Moon Fish ( } M \text {. } \\
\text { maculata) }\end{array}$ & Bogor & Pengecer/Retailer & $\begin{array}{l}\text { Dekat penjual sayuran, cabe ,beras dan } \\
\text { kacang/Close to vegetable, chili, rice and bean } \\
\text { retailers }\end{array}$ \\
\hline 16. & $\begin{array}{l}\text { Bandeng/Milk Fish (C. } \\
\text { chanos) }\end{array}$ & Bogor & Pengecer/Retailer & $\begin{array}{l}\text { Dekat penjual sayuran, cabe ,beras dan } \\
\text { kacang/Close to vegetable, chili, rice and bean } \\
\text { retailers }\end{array}$ \\
\hline 17. & $\begin{array}{l}\text { Tongkol/Mackerel Tuna } \\
\text { (E. affinis) }\end{array}$ & Jakarta (Muara Angke) & Pengecer/Retailer & Tidak higienis, pengap/Unhygienis, stuffy \\
\hline 18. & $\begin{array}{l}\text { Tongkol/Mackerel Tuna } \\
\text { (E. affinis) }\end{array}$ & Jakarta (Muara Angke) & Pengolah/ Processor & $\begin{array}{l}\text { Tidak higienis, pengap dan dekat dengan } \\
\text { selokan/Unhygienics, stuffy, and close to ditch }\end{array}$ \\
\hline 19. & $\begin{array}{l}\text { Bandeng/Milk Fish (C. } \\
\text { chanos) }\end{array}$ & $\begin{array}{l}\text { Jakarta (Pasar } \\
\quad \text { Palmerah) }\end{array}$ & Pengecer/Retailer & $\begin{array}{l}\text { Dekat dengan penjual sayuran dan bumbu, cabe } \\
\text { dan buah/Close to vegetable, spices, chili and } \\
\text { fruits retailers }\end{array}$ \\
\hline 20. & $\begin{array}{l}\text { Layang/Indian Scad ( } D . \\
\text { russelli) }\end{array}$ & $\begin{array}{l}\text { Jakarta (Pasar } \\
\text { Palmerah) }\end{array}$ & Pengecer/Retailer & $\begin{array}{l}\text { Dekat dengan penjual sayuran dan bumbu, cabe } \\
\text { dan buah/Close to vegetable, spices, chili and } \\
\text { fruits retailers }\end{array}$ \\
\hline 21. & $\begin{array}{l}\text { Kembung lelaki/ Indian } \\
\text { Mackerel (Rastrelliger } \\
\text { kanagurta) }\end{array}$ & $\begin{array}{l}\text { Jakarta (Pasar } \\
\text { Palmerah) }\end{array}$ & Pengecer/Retailer & $\begin{array}{l}\text { Dekat dengan penjual sayuran dan bumbu, cabe } \\
\text { dan buah/Close to vegetable, spices, chili and } \\
\text { fruits retailers }\end{array}$ \\
\hline 22. & $\begin{array}{l}\text { Tongkol/Mackerel Tuna } \\
\text { (E. affinis) }\end{array}$ & $\begin{array}{l}\text { Jakarta (Pasar } \\
\text { Kebayoran Lama) }\end{array}$ & Pengecer/Retailer & $\begin{array}{l}\text { Dekat penjual sayuran dan cabe/Close to } \\
\text { vegetable and chili retailers }\end{array}$ \\
\hline 23. & $\begin{array}{l}\text { Layang/Indian Scad }(D . \\
\text { russelli) }\end{array}$ & $\begin{array}{l}\text { Jakarta (Pasar } \\
\text { Kebayoran Lama) }\end{array}$ & Pengecer/Retailer & $\begin{array}{l}\text { Dekat penjual sayuran dan cabe/Close to } \\
\text { vegetable and chili retailers }\end{array}$ \\
\hline 24. & $\begin{array}{l}\text { Bandeng/Milk Fish (C. } \\
\text { chanos) }\end{array}$ & $\begin{array}{l}\text { Jakarta (Pasar } \\
\text { Kebayoran Lama) }\end{array}$ & Pengecer/Retailer & $\begin{array}{l}\text { Dekat penjual sayuran dan cabe/Close to } \\
\text { vegetable and chili retailers }\end{array}$ \\
\hline 25. & $\begin{array}{l}\text { Cakalang/Skipjack Tuna } \\
\text { (Katsuwonus pelamis) }\end{array}$ & Bandung & Pengolah 1/ Processor 1 & $\begin{array}{l}\text { Di rumah tinggal, bersih namun sedikit pengap/In } \\
\text { the house, clean and stuffy }\end{array}$ \\
\hline 26. & $\begin{array}{l}\text { Mas/Carp Fish (Cyprinus } \\
\text { carpio) }\end{array}$ & Bandung & Pengolah 1/ Processor 1 & $\begin{array}{l}\text { Di rumah tinggal, bersih namun sedikit pengap/In } \\
\text { home stay, clean and stuffy }\end{array}$ \\
\hline 27. & $\begin{array}{l}\text { Salem/Rainbow Runner } \\
\text { (Elagatis bipinnulata) }\end{array}$ & Bandung & Pengolah 1/ Processor 1 & $\begin{array}{l}\text { Di rumah tinggal, bersih namun sedikit pengap/In } \\
\text { home stay, clean and stuffy }\end{array}$ \\
\hline 28. & $\begin{array}{l}\text { Layang/Indian Scad (D. } \\
\text { russelli) }\end{array}$ & Bandung & Pengolah 2/ Processor 2 & $\begin{array}{l}\text { Dekat dengan perumahan penduduk, kurang } \\
\text { bersih, pengap/Close to residential, dirty, stuffy }\end{array}$ \\
\hline 29. & $\begin{array}{l}\text { Bandeng/Milk Fish (C. } \\
\text { chanos) }\end{array}$ & Cirebon & Pengolah 2/ Processor 2 & $\begin{array}{l}\text { Dekat dengan perumahan penduduk, kurang } \\
\text { bersih, pengap/Close to resindential, dirty and } \\
\text { stuffy }\end{array}$ \\
\hline 30. & $\begin{array}{l}\text { Tongkol/Mackerel Tuna } \\
\text { (E. affinis) }\end{array}$ & Cirebon & Pengolah 2/ Processor 2 & $\begin{array}{l}\text { Dekat dengan perumahan penduduk, kurang } \\
\text { bersih, pengap/Close to resindential, dirty and } \\
\text { stuffy }\end{array}$ \\
\hline
\end{tabular}


2009). Inkubasi kapang dilakukan pada suhu $25^{\circ} \mathrm{C}$ selama lima hari. Pemilihan isolat pada tahap awal identifikasi dilakukan berdasarkan pada warna dan tekstur koloni yang berbeda yang dilihat secara morfologi pada cawan petri.

\section{Identifikasi kapang}

Identifikasi kapang dilakukan dengan menggunakan pendekatan secara morfologi (makroskopis dan mikroskopis) dan molekuler (Crous et al., 2009). Dalam identifikasi secara morfologi, masing-masing koloni yang memiliki warna dan tekstur yang berbeda dipindahkan ke media malt extract agar (MEA) dan czapeks yeast agar (CYA). Spora diambil dengan menggunakan jarum ose, dimasukkan ke dalam cairan semi solid (bacto agar $0,2 \%$ dengan $0,05 \%$ tween 80) diaduk dan diinokulasi dengan cara menitikkannya pada media MEA dan CYA dalam cawan petri pada 3 titik dan diinkubasi pada suhu ruang, antara $25-30{ }^{\circ} \mathrm{C}$ selama 5-7 hari. Pengamatan makroskopis meliputi warna permukaan koloni, warna sebalik (reverse side), diameter, dan tekstur koloni kapang. Pengamatan mikroskopis dilakukan dengan mengambil koloni kapang pada cawan petri menggunakan jarum ose steril, diletakkan pada gelas objek, ditetesi dengan lactophenol blue kemudian ditutup dengan cover glass, diamati pada mikroskop pada perbesaran 100-1000 x. Morfologi mikroskopis kapang dilihat dari bentuk badan buah (konidiofora, vesikel, metula, fialid, dan konidia).

Dalam identifikasi secara molekuler, DNA kapang diekstraksi menggunakan DNeasy plant mini kit (Qiagen). Primer yang digunakan adalah ITS1 (5'-TCC GTA GGT GGA CCT GCG G-3') dan ITS4 (5'-TCC TCC GCT TAT TGA TAT GC-3'). Reaksi Polymerase Chain

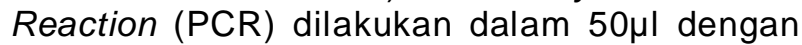
komponen-komponen yaitu $25 \mu \mathrm{L}$ PCR master mix Qiagen, $1 \mu \mathrm{L}$ Primer a (ITS 1), $1 \mu \mathrm{L}$ Primer b (ITS 4),
$20 \mu \mathrm{L}$ Nuclease Free Water, dan $3 \mu \mathrm{L}$ cetakan DNA. Amplifikasi DNA menggunakan siklus suhu sebagai berikut : denaturasi pada suhu $94^{\circ} \mathrm{C}$ selama 2 menit, suhu $94^{\circ} \mathrm{C}$ selama 1 menit, suhu $60^{\circ} \mathrm{C}$ selama 1 menit, suhu $72^{\circ} \mathrm{C}$ selama 1 menit, dan suhu $72^{\circ} \mathrm{C}$ selama 5 menit. Semua tahapan dilakukan dengan 35 siklus. Sampel PCR dikirim ke $1^{\text {st }}$ BASE (Malaysia) untuk sequencing DNA. Identitas sekuen kapang dicari dengan membandingkannya dengan sekuen homolog yang ada di GenBank (National Center for Biotechnology Information) menggunakan program BLAST (Basic Local Alignment Search Tool) (http://blast.ncbi.n/m.nih.gov/Blast.cgi)

\section{HASIL DAN BAHASAN}

\section{Kadar Garam dan Aktivitas Air Ikan Pindang}

Hasil pengamatan terhadap kadar garam dan $\mathrm{a}_{\mathrm{w}}$ setiap jenis ikan pindang disajikan pada Tabel 2. Pada umumnya tongkol, bandeng dan layang merupakan jenis ikan yang paling banyak digunakan sebagai bahan baku pindang dan banyak dijual di pasar tradisional.

Rata-rata kadar garam ikan pindang dari seluruh sampel (30 sampel) adalah $3,51 \pm 1,70 \%$ dengan $a_{w}$ $0,96 \pm 0,02$ (Tabel 2). Variasi garam yang tinggi pada pindang ikan tongkol $(3,06 \pm 2,14 \%)$, layang $(2,30 \pm 1,80 \%)$, bandeng $(3,64 \pm 1,14 \%)$, dan semar $(1,5 \pm 0,42 \%)$, dimungkinkan karena pemberian garam dalam pengolahan ikan pindang tidak terstandar, hanya berdasarkan perkiraan pengolah dan perbedaan cara mengolahnya (pindang naya, pindang presto dan pindang badeng). Pindang naya merupakan pemindangan dengan cara perebusan dalam larutan air garam dengan waktu perebusan relatif singkat (berkisar 5-30 menit tergantung ukuran ikannya) seperti pada ikan layang, salem, kembung, mas, dan

Tabel 2. Data kadar garam dan aktivitas air $\left(\mathrm{a}_{\mathrm{w}}\right)$ ikan pindang

Table 2. Salt content and water activiy $\left(a_{w}\right)$ of boiled salted fish

\begin{tabular}{lccc}
\hline \multicolumn{1}{c}{$\begin{array}{c}\text { Nama Ikan/ } \\
\text { Fish Name }\end{array}$} & $\begin{array}{c}\text { Jumlah Sampel/ } \\
\text { Number of } \\
\text { Sample }\end{array}$ & $\begin{array}{c}\text { Kadar Garam/ } \\
\text { Salt Content } \\
(\%)^{*}\end{array}$ & $\begin{array}{c}\text { Aktivitas Air/ } \\
\text { Water Activity } \\
\left(\mathbf{a}_{\mathbf{w}}\right)^{*}\end{array}$ \\
\hline Semar/Moon Fish (Mene maculata) & 2 & $1.50 \pm 0.42$ & $0.96 \pm 0.01$ \\
Tongkol/Mackerel Tuna (Euthynnus affinis) & 11 & $3.06 \pm 2.14$ & $0.96 \pm 0.02$ \\
Bandeng/Milk Fish(Chanos chanos) & 9 & $3.64 \pm 1.14$ & $0.95 \pm 0.02$ \\
Layang/Indian Scad (Decapterus russelli) & 4 & $2.30 \pm 1.80$ & $0.96 \pm 0.02$ \\
Mas/Carp Fish (Cyprinus carpio) & 1 & $7.30 \pm 0.02$ & $0.94 \pm 0.01$ \\
Cakalang/Skipjack Tuna (Katsuwonus pelamis) & 1 & $7.78 \pm 0.02$ & $0.95 \pm 0.01$ \\
Salem/Rainbow Runner (Elagatis bipinnulatus) & 1 & $6.42 \pm 0.01$ & $0.95 \pm 0.01$ \\
Kembung Lelaki/Indian Mackerel (Rastrelliger kanagurta) & 1 & $5.17 \pm 0.02$ & $0.98 \pm 0.01$ \\
\hline
\end{tabular}

*Nilai rata-rata dari sampel pindang dari jenis ikan yang sama/The average value of boiled salted fish sample from the same species 
semar. Kualitas pindang naya sangat tergantung kepada kebiasaan pengolah dan umumnya ukuran ikan lebih kecil dibandingkan pindang badeng. Sedangkan pindang badeng adalah pemindangan dalam wadah paso/badeng dengan penaburan garam dan direbus selama 2-8 jam tergantung dari ukuran ikan, seperti pada ikan bandeng, tongkol dan cakalang. Pindang presto adalah pemindangan dengan menggunakan alat dengan suhu dan tekanan tertentu (autoclave) sehingga durinya menjadi lunak, seperti pada ikan bandeng

Selain kadar garam, pertumbuhan kapang pada sampel ikan pindang sangat erat hubungannya dengan aktivitas air $\left(\mathrm{a}_{\mathrm{w}}\right)$. Menurut Pitt dan Hocking (2009) mikroorganisme mempunyai kemampuan tumbuh masing-masing berdasarkan nilai $\mathrm{a}_{\mathrm{w}}$. Bakteri pada umumnya tumbuh pada media dengan $\mathrm{a}_{\mathrm{w}} 0,9$, khamir 0,85 , kapang 0,65-0,95. Beberapa jenis kapang xerofilik dapat tumbuh pada bahan pangan dengan $\mathrm{a}_{\mathrm{w}}$ 0,60 (Rahayu \& Nurwitri, 2012). Kapang mampu tumbuh pada kondisi $a_{w}$ rendah dan optimum pada suhu $26-30^{\circ} \mathrm{C}$ (FAO, 1981 dalam Ibrahim, 1986).

\section{Isolasi Kapang}

Hasil isolasi kapang menunjukkan bahwa sampel ikan pindang yang diperoleh seluruhnya terkontaminasi kapang. Dari 30 sampel ikan pindang, diperoleh isolat sebanyak 119 isolat. Jumlah isolat kapang yang diisolasi dari sampel ikan pindang berdasarkan lokasi dan jenis ikan disajikan pada Tabel 3 dan 4. Menurut Nasran (1980) dalam Seila (2014) masalah utama pada ikan pindang adalah tumbuhnya kapang.

Pada penelitian ini, pengambilan sampel ikan pindang di lokasi-lokasi tersebut dilakukan di tempat pengolah dan pengecer. Diduga bahwa kontaminasi kapang, telah terjadi sejak dari tempat pengolahan maupun lingkungan pasar tradisional. Pada umumnya kontaminasi spora kapang pada ikan pindang berasal dari lingkungan sekitar pengolahan dan wadah/ peralatan yang digunakan dalam pengolahan (Indriati et al., 2008; Indriati dan Murniyati, 2012). Hermana, Hidayah, dan Indriati (2016) melaporkan bahwa ikan pindang di salah satu pengolah pindang di P. Ratu terkontaminasi oleh kapang, demikian juga ikan pindang yang berasal dari Sukabumi (Indriati \& Murniyati, 2012). Menurut Rahayu, Sarjono, dan Samson (2014) kapang tumbuh optimum pada lingkungan yang hangat $\left(25-30^{\circ} \mathrm{C}\right)$. Pertumbuhan mikroorganisme seperti kapang ini dapat dicegah dengan menerapkan sanitasi dan higiene yang baik dari tahap pengolahan sampai pemasaran atau pada tahap penyimpanan, misalnya dengan mengatur

Tabel 3. Jumlah isolat kapang yang diperoleh berdasarkan lokasi pengambilan sampel Table 3. Number of fungal isolates based on sampling locations

\begin{tabular}{lcc}
\hline $\begin{array}{c}\text { Lokasi Pengambilan Sampel/ } \\
\text { Sampling Location }\end{array}$ & $\begin{array}{c}\text { Jumlah Isolat/ } \\
\text { Number of Isolates }\end{array}$ & $\begin{array}{c}\text { Persentase Isolat/ } \\
\text { Percentage of isolates (\%) }\end{array}$ \\
\hline Bandung & 9 & 7.56 \\
Bogor & 10 & 8.40 \\
Cirebon & 23 & 19.33 \\
Jakarta & 37 & 31.09 \\
P.Ratu & 25 & 21.01 \\
Semarang & 15 & 12.61 \\
\hline Total & 119 & 100.00 \\
\hline
\end{tabular}

Tabel 4. Jumlah isolat kapang yang diperoleh berdasarkan jenis ikan Table 4. Number of fungal isolates based on fish species

\begin{tabular}{lcc}
\hline \multicolumn{1}{c}{$\begin{array}{c}\text { Nama Ikan/ } \\
\text { Fish Name }\end{array}$} & $\begin{array}{c}\text { Jumlah Isolat/ } \\
\text { Number of Isolate }\end{array}$ & $\begin{array}{c}\text { Persentase Isolat/ } \\
\text { Percentage of isolates (\%) }\end{array}$ \\
\hline Semar/Moon Fish (Mene maculata) & 9 & 7.56 \\
Tongkol/Mackerel Tuna (Euthynnus affinis) & 26 & 21.85 \\
Bandeng/Milk Fish (Chanos chanos) & 40 & 33.61 \\
Layang/Indian Scad (Decapterus russelli) & 28 & 23.53 \\
Mas/Carp Fish (Cyprinus carpio) & 4 & 3.36 \\
Cakalang/Skipjack Tuna (Katsuwonus pelamis) & 4 & 3.36 \\
Salem/Rainbow Runner (Elagatis bipinnulata) & 5 & 4.20 \\
Kembung lelaki/Indian Mackarel (Rastrelliger & 3 & 2.52 \\
\hline Total & 119 & 100.00 \\
\hline
\end{tabular}


kelembaban $<65 \%$, dan suhu $<10^{\circ} \mathrm{C}$ (Kow et al., 1998). Jumlah isolat kapang tertinggi yang diisolasi dari ikan pindang berasal dari Jakarta yaitu sebesar $31,09 \%$ (Tabel 3). Hal ini kemungkinan berkaitan dengan sampel ikan pindang yang diambil dari Jakarta sebagian besar diperoleh dari pengecer (pasar), di mana penjual pindang di tingkat pengecer pada umumnya berjualan langsung di lantai (tidak menggunakan meja) dan di dekat penjual sayuran, cabe, beras dan kacang. Menurut Rahayu et al., (2014) lingkungan pasar yang tidak higienis merupakan salah satu sumber kontaminasi paling besar. Sampel ikan asin yang diambil dari pasar Beringharjo, Yogyakarta dan pasar Kenjeran, Surabaya seluruhnya terkontaminasi kapang (Rahayu, Kamil, Damara, \& Sidar, 2016). Ikan asin yang diperoleh dari berbagai pasar tradisonal di Jakarta seluruhnya terkontaminasi kapang (Santoso, Sari, \& Sembiring, 1999; Wheeler Hocking, Pitt, \& Anggawati, 1986).

Berdasarkan Tabel 4, persentase jumlah isolat kapang relatif lebih banyak ditemukan pada tiga jenis ikan pindang yaitu ikan bandeng $(33,61 \%)$, layang $(23,53 \%)$ dan tongkol $(21,85 \%)$ yang mempunyai kadar garam relatif rendah $(<4 \%)$, sedangkan jenis ikan lainnya yang mempunyai kadar garam berkisar $5-8 \%$ jumlah isolat yang ditemukan relatif lebih sedikit (Tabel 2). Hal ini menunjukkan adanya korelasi langsung antara pertumbuhan kapang pada ikan pindang dengan kadar garam. Hasil ini mirip dengan penemuan Seilla (2014) pada ikan asin yang berasal dari Kenya, bahwa pada kadar garam 5\%, pertumbuhan kapang lebih tinggi dibandingkan dengan pertumbuhan kapang pada kadar garam $10 \%$ dan $20 \%$. Darmoredjo dan Saleh (1972) dalam Ibrahim (1986) menyatakan bahwa penambahan garam $15-25 \%$ dalam proses pemindangan dapat menghambat pertumbuhan kapang, selain untuk memberikan citarasa yang lebih disukai dan tekstur pindang yang kompak (Ibrahim, 1982). Atapatu dan Samarajeewa
(1990) menyatakan bahwa kapang yang diisolasi dari ikan asin di Srilangka tumbuh baik pada ikan asin dengan kadar garam $<10 \%$. Beberapa kapang terhambat pertumbuhannya pada kadar garam $20 \%$ dan tidak dapat tumbuh pada kadar garam $30 \%$.

\section{Identifikasi Kapang}

Hasil identifikasi secara morfologi terhadap 119 isolat kapang yang berhasil diisolasi dari sampel ikan pindang menunjukkan bahwa isolat-isolat tersebut termasuk dalam tujuh marga dengan isolat terbanyak berasal dari genus Aspergillus (45,38\%) dan Penicillium (40,34\%). Isolat lainnya sebanyak $14,28 \%$ terdiri dari genus Cladosporium, Eurotium, Fusarium, Loweporus, dan Syncephalastrum (Tabel 5). Dari marga Aspergillus, diperoleh tujuh jenis kapang, yaitu $A$. flavus, $A$. fumigatus, $A$. niger, $A$. ochraceus, $A$. oryzae, A. sydowii, dan A. Terreus, sedangkan dari genus Penicilium diperoleh tiga jenis kapang, yaitu $P$. chermesinum, P. citrinum, dan P. chrysogenum. Menurut Wheeler et al. (1986) jenis kapang yang sering ditemukan pada sampel ikan asin adalah dari marga Aspergillus (17 jenis) dan Penicillium (20 jenis). Populasi jenis kapang yang diisolasi dari ikan pindang disajikan pada Gambar 2.

Hasil identifikasi molekuler menunjukkan bahwa isolat-isolat kapang yang sudah diisolasi dari 30 sampel ikan pindang masuk ke dalam 16 spesies (Tabel 6). Hasil identifikasi secara morfologi (Tabel 5) dengan tingkat populasi masing-masing jenis kapang disajikan pada Gambar 1. Tingkat populasi kapang tertinggi pada ikan pindang yaitu $P$. chermesinum $(80 \%)$, diikuti berturut-turut oleh jenis $P$. citrinum (73,3\%), A. fumigatus (56,6\%), A. flavus (53,3\%), A. niger (46,7\%), E. chevalieri (26,7\%), dan populasi 11 jenis lainnya $\leq 10 \%$ ( $A$. ochraceus, $A$. oryzae, $A$. sydowii, A. terreus, Cladosporium allicinum, F. cerialis, F. graminearum, Loweporus sp., P.chrysogenum, dan $S$. racemosum). Penelitian ini mendukung laporan

Tabel 5 Daftar marga kapang hasil isolasi dari ikan pindang

Table 5. Fungal genera isolated from boiled salted fish

\begin{tabular}{lcc}
\hline \multicolumn{1}{c}{ Nama Genus/ } & $\begin{array}{c}\text { Persentase Isolat/ } \\
\text { Percentage of Isolates (\%) }\end{array}$ & $\begin{array}{c}\text { Jumlah Spesies/ } \\
\text { Number of Species }\end{array}$ \\
\hline Aspergillus & 45.38 & 7 \\
Penicillium & 40.34 & 3 \\
Eurotium & 6.72 & 1 \\
Fusarium & 2.52 & 2 \\
Syncephalastrum & 2.52 & 1 \\
Loweporus & 1.68 & 1 \\
Cladosporium & 0.84 & 1 \\
\hline Total & 100.00 & 16 \\
\hline
\end{tabular}


penelitian Indriati et al. (2008) yang menyatakan bahwa jenis kapang yang diisolasi dari ikan pindang tongkol terdiri dari $A$. flavus, $A$. niger, $A$. ochraceus, $P$. chrysogenum, dan Rhizopus oryzae. Jenis kapang $P$. citrinum, A. niger, A. flavus, A. fumigatus, dan $E$. chevalieri ternyata juga ditemukan pada ikan asin, ikan asap, dan ikan olahan lainnya (Pitt \& Hocking, 2009). Indriati dan Murniyati (2012) melaporkan bahwa ikan pindang tongkol yang berasal dari pengolah di Sukabumi terkontaminasi oleh A. clavatus, A. flavus, $P$. citrinum, dan $P$. citreonigrum.

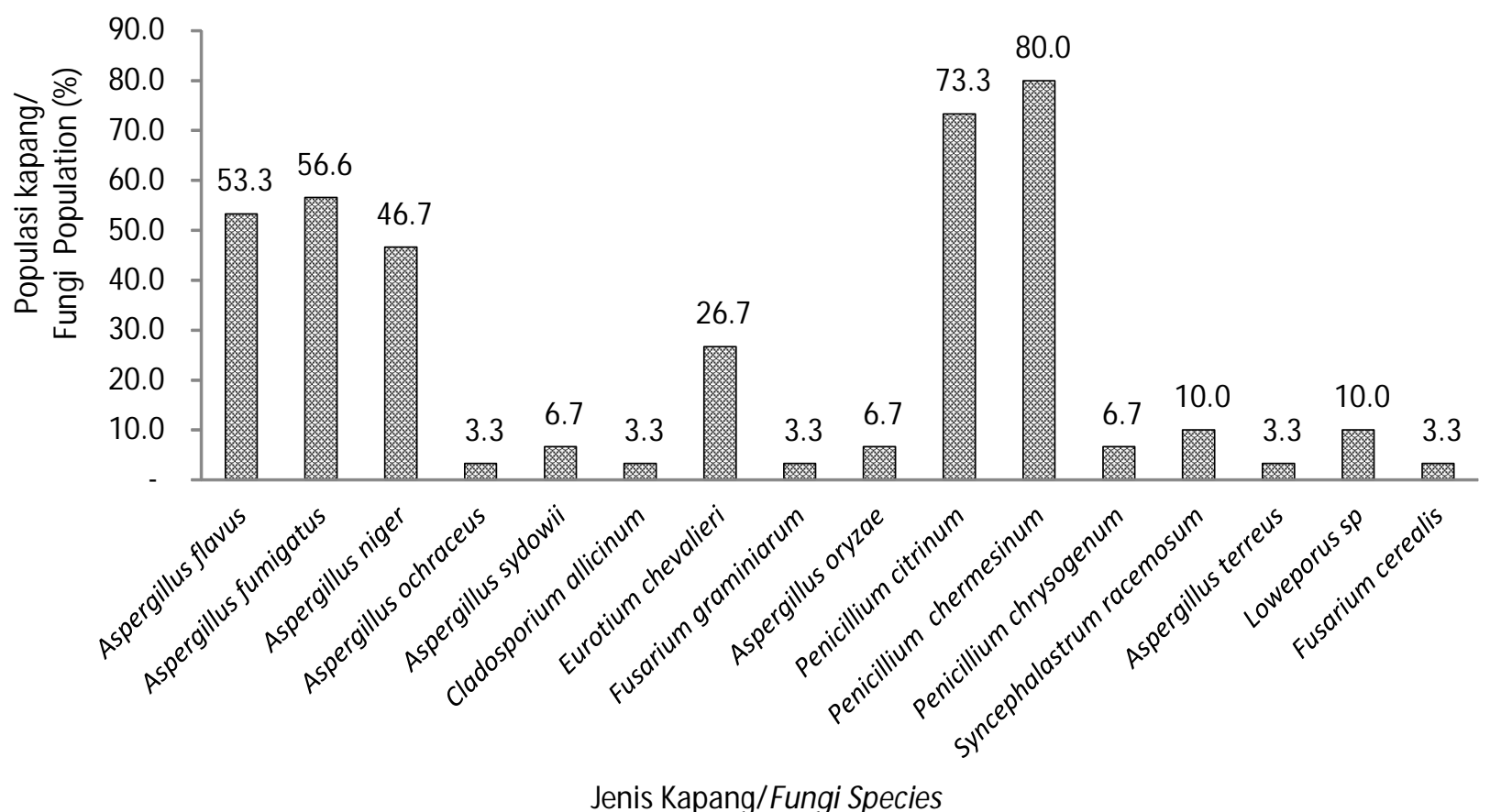

Gambar 1. Populasi jenis kapang hasil isolasi dari ikan pindang

Figure 1. Population of fungal species isolated from boiled salted fish

Tabel 6 Hasil BLAST sekuen DNA kapang asal ikan pindang

Table 6. BLAST result of fungal DNA sequences from boiled salted fish

\begin{tabular}{clcc}
\hline $\begin{array}{c}\text { Kode Isolat/ } \\
\text { Isolate Code }\end{array}$ & $\begin{array}{c}\text { Jenis Kapang/ } \\
\text { Fungal Species }\end{array}$ & $\begin{array}{c}\text { Kemiripan/ } \\
\text { Similarity (\%) }\end{array}$ & $\begin{array}{c}\text { Nomor Akses/ } \\
\text { Accession Number }\end{array}$ \\
\hline BSF 2 & A. fumigatus & 99 & KU 561918.1 \\
BSF 3 & E. chevalieri & 100 & KX 463338.1 \\
BSF 4 & A. niger & 100 & EU 440768.1 \\
BSF 5 & A. flavus & 100 & KX 067855.1 \\
BSF 6 & A. oryzae & 100 & HQ 285542.1 \\
BSF 7 & S. racemosum & 99 & JN 315030.1 \\
BSF 9 & P. chermesinum & 99 & KJ 767049.1 \\
BSF 11 & F. graminearum & 100 & XM 011321240.1 \\
BSF 16 & Loweporus sp. & 95 & KJ 654481.1 \\
BSF 17 & P. chrysogenum & 100 & AM 920437.1 \\
BSF 25 & A. sydowii & 100 & KJ 524908.1 \\
BSF 27 & C. allicinum & 100 & KX 611004.1 \\
BSF 28 & F. cerealis & 100 & MF434844.1 \\
BSF 29 & A. ochraceus & 99 & KX 610750.1 \\
BSF 35 & A. terreus & 99 & KT 310979.1 \\
BSF 37 & P. citrinum & 100 & JN 624897 \\
\hline
\end{tabular}




\section{P. chermesinum (Gambar 2)}

Merupakan salah satu kapang endofit dengan suhu pertumbuhan $5-30{ }^{\circ} \mathrm{C}$. Kapang ini menghasilkan metabolit sekunder yang memiliki aktivitas biologi seperti turunan polyketida, plastatin, luteosporin, xanthomegnin, azaphilones, p-terphenyls dan costoclavine (Darsih, Prachyawarakorn, Mahidol, Ruchirawat,\& Kittakoop, 2017).

\section{P. citrinum (Gambar 3)}

Termasuk kapang mesofilik dengan suhu pertumbuhan minimum $5^{\circ} \mathrm{C}$ dan suhu optimum 26-
$30{ }^{\circ} \mathrm{C}$ dan $\mathrm{a}_{w} 0,80-0,84$. Kapang ini menghasilkan toksin sitrinin dan keberadaanya menyebar luas pada komoditas pangan di Indonesia seperti ikan asin, sorghum, kemiri, lada, ketumbar (Pitt \& Hocking, 2009).

\section{A. fumigatus (Gambar 4)}

A. fumigatus merupakan kapang termofilik dengan suhu pertumbuhan minimum $12^{\circ} \mathrm{C}$ dan suhu optimum 40-42 ${ }^{\circ} \mathrm{C}$. Kapang ini menghasilkan mikotoksin fumitremorgens, verruculogen, dan glikotoksin yang berperan dalam terjadinya penyakit pada hewan (Cole, 1981; Dorner, Cole, \& Hill, 1984; Frisvad, Thrane,
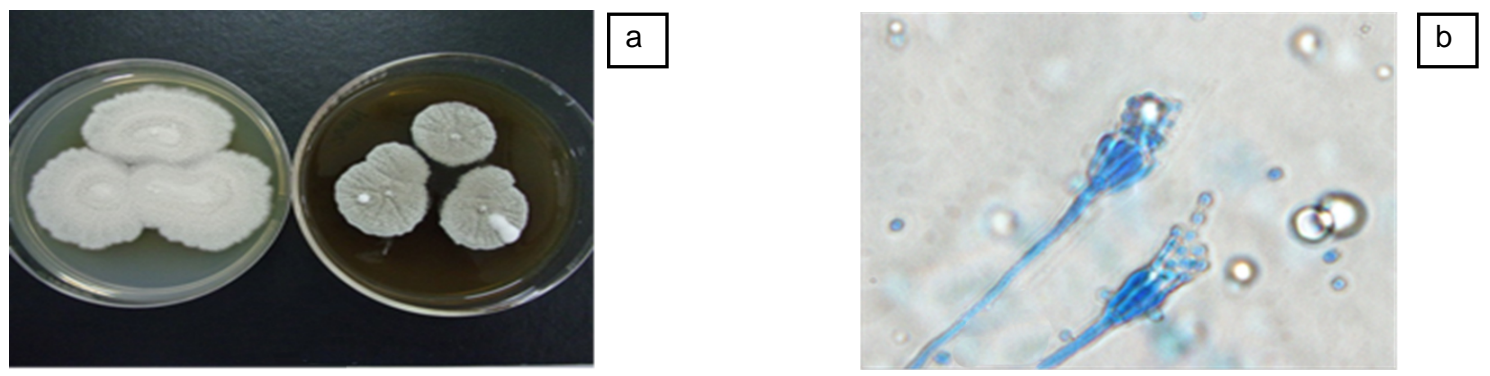

Gambar 2. Isolat P. chermesinum BSF 9, (a) Czapeks Yeast Agardan Malt Extract Agar 7 hari, (b) Mikroskopis perbesaran 1000x

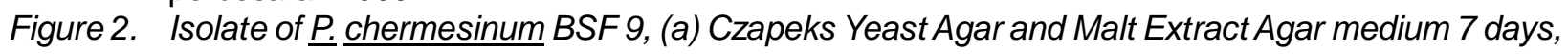
(b) Microscopic magnification at $1000 x$
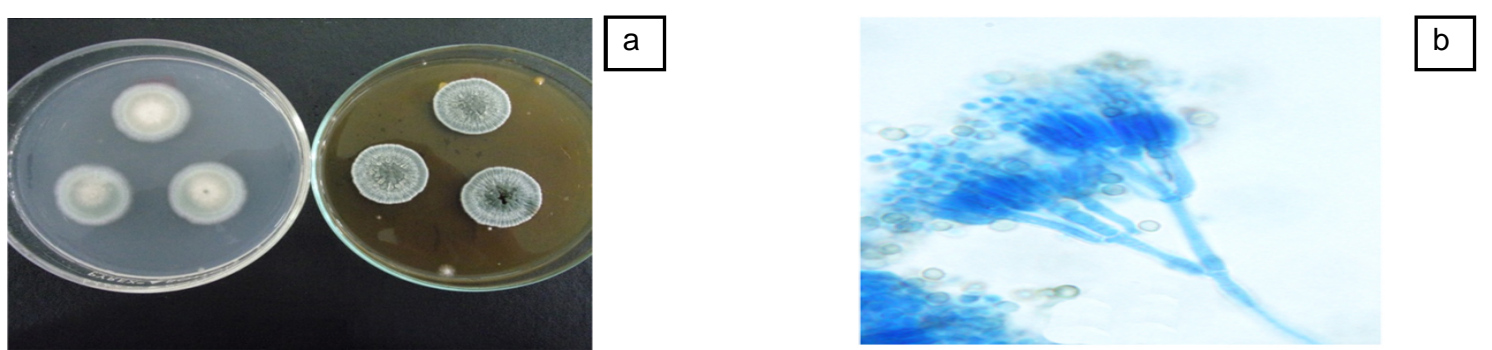

Gambar 3. Isolat P. citrinum BSF 37, (a) Czapeks Yeast Agar dan Malt Extract Agar 7 hari, (b) Mikroskopis perbesaran $1000 \mathrm{x}$

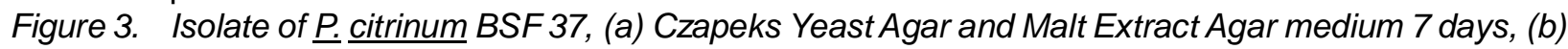
Microscopic magnification at $1000 x$
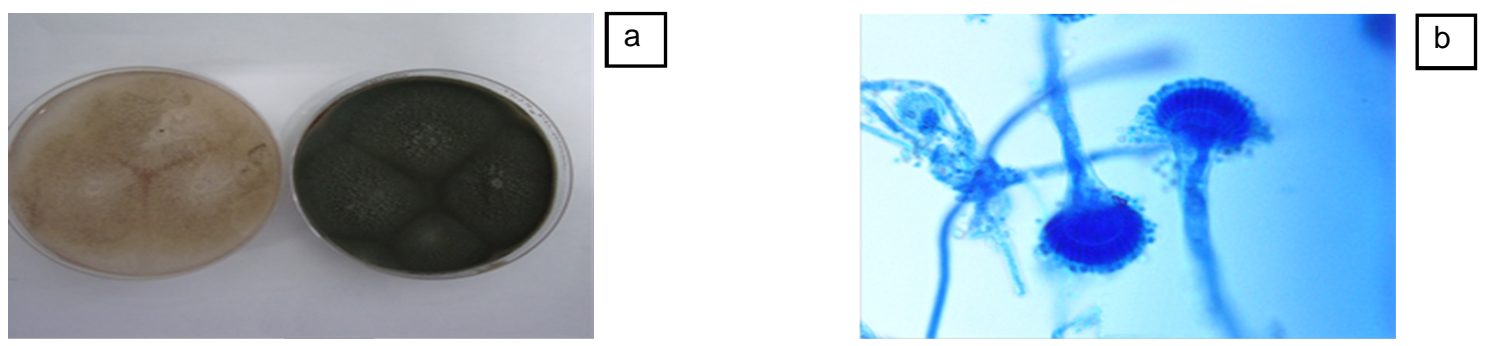

Gambar 4. Isolat A. fumigatus BSF 2, (a) Czapeks Yeast Agar dan Malt Extract Agar 7 hari, (b) Mikroskopis perbesaran $1000 \mathrm{x}$

Figure 4. Isolate of A. fumigatus BSF 2, (a) Czapeks Yeast Agar and Malt Extract Agar medium 7 days, (b) Microscopic magnification at $1000 x$ 
Samson, \& Pitt, 2006). Pada manusia, A. fumigatus dapat menyebabkan aspergilosis paru-paru (De Hoog, Guarro, Gene, \& Figucras, 2000). Aspergillus fumigatus banyak terdapat pada kacang-kacangan (Adebajo \& Diyaolu, 2003), ikan asin, roti, snackjagung, biji melon, asinan mangga, dan keju (Pitt \& Hocking, 2009).

\section{A. flavus (Gambar 5)}

Kapang yang tahan panas, tumbuh cepat pada suhu $25^{\circ} \mathrm{C}$ dan $37^{\circ} \mathrm{C}$ dengan suhu optimum $33^{\circ} \mathrm{C}$. Aspergillus flavus merupakan penghasil aflatoksin yang bersifat karsinogenik (Kurtzman, Smiley, Robnet, \& Wicklow, 1986). Pitt dan Hocking (2009) mengatakan bahwa beberapa ikan olahan dari Nigeria terkontaminasi oleh $A$. flavus.

\section{A. niger (Gambar 6)}

Kapang mesofilik yang tumbuh optimum pada $\mathrm{a}_{\mathrm{w}}$ 0,77 dan suhu $35^{\circ} \mathrm{C}$. Menurut Abarca, Bragulat, Castella, dan Cabanes (1994), 2 dari 19 isolat $A$. niger menghasilkan okratoksin A dan fumonisin B2 (Frisvad et al., 2007).

\section{E. chevalieri (Gambar 7)}

Kapang serofilik yang paling tahan panas, dapat bertahan pada pemanasan $70^{\circ} \mathrm{C}$ selama 10 menit
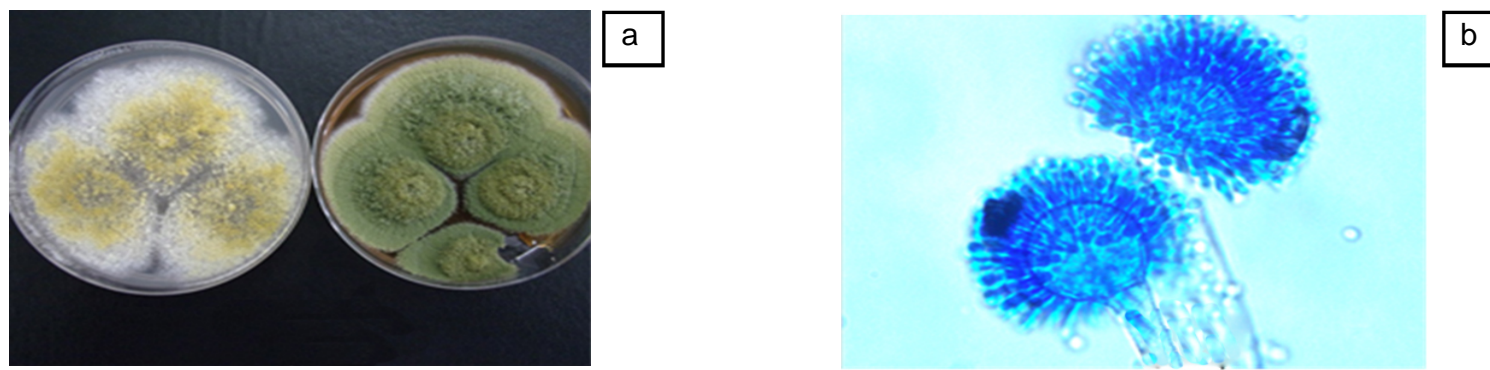

Gambar 5. Isolat A. flavus BSF 5, (a) Czapeks Yeast Agar dan Malt Extract Agar 7 hari, (b) Mikroskopis perbesaran 1000x

Figure 5. Isolate of A. flavus BSF 5, (a) Czapeks Yeast Agar and Malt Extract Agar medium 7 days, (b) Microscopic magnification at $1000 x$
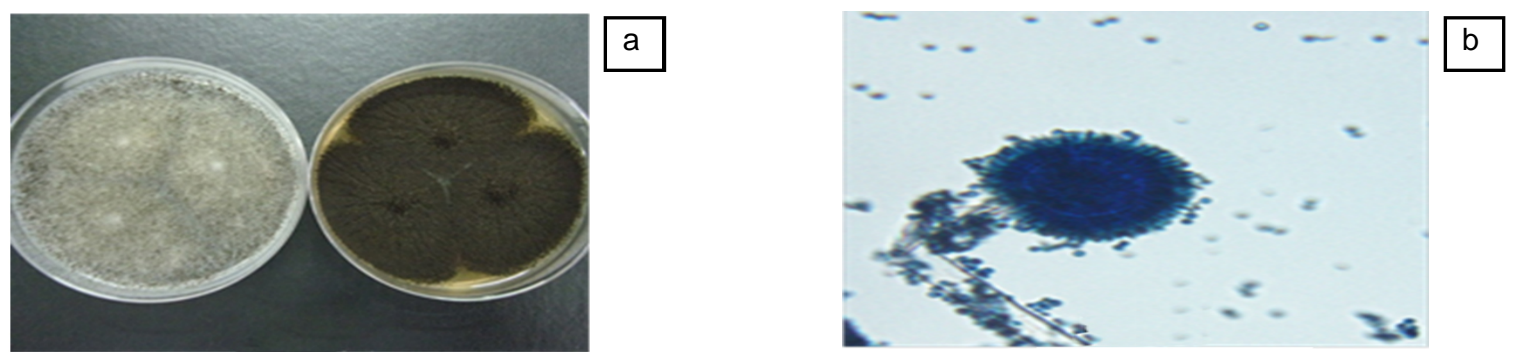

Gambar 6. Isolat A. niger BSF 4, (a) Czapeks Yeast Agar dan Malt Extract Agar 7 hari, (b) Mikroskopis perbesaran 1000x

Figure 6. Isolate of $\underline{A}$. niger BSF 4, (a) Czapeks Yeast Agar and Malt Extract Agar medium 7 days, (b) Microscopic magnification at $1000 x$
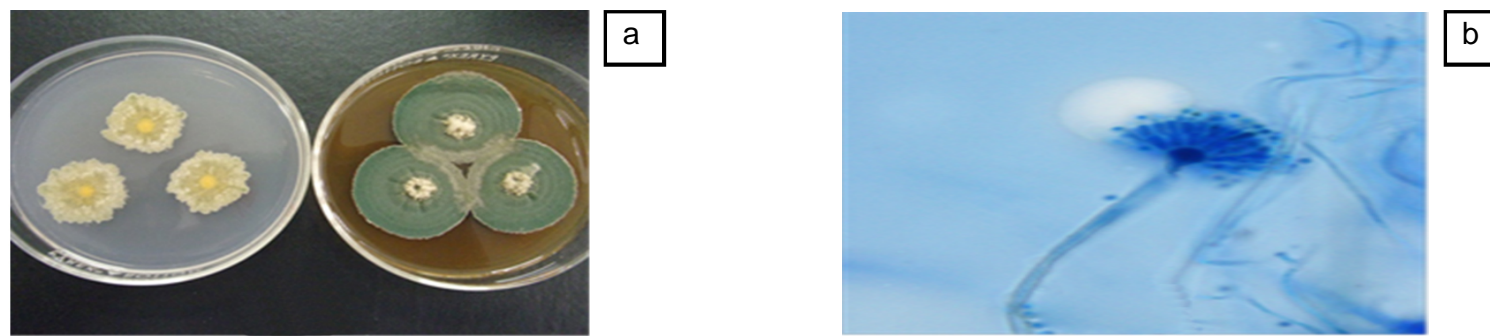

Gambar 7. Isolat E. chevalieriBSF 3, (a) Czapeks Yeast Agardan Malt Extract Agar 7 hari, (b) Mikroskopis perbesaran 1000x

Figure 7. Isolate of E. chevalieri BSF 3 (a) Czapeks Yeast Agar and Malt Extract Agar medium 7 days, (b) Microscopic magnification at $1000 x$ 
pada medium dengan $\mathrm{a}_{\mathrm{w}} 0,98$ dan $\mathrm{pH} 3$, banyak ditemukan pada kacang-kacangan, daging asap, ikan asin, dan ikan olahan lainnya (Pitt \&Hocking, 2009).

Beberapa jenis kapang yang diisolasi dari ikan pindang ini berpotensi menghasilkan mikotoksin. Salunkhe (1978) dalam Wheeler et al. (1986) melaporkan bahwa kapang Eurotium sp., $A$. fumigatus, $P$. expansum, $P$. viridicatum, Penicillium spp., Alternaria sp., dan Cladosporium sp. mempunyai sifat toksik terhadap embrio ayam dan potensial menghasilkan mikotoksin. Rahmadi dan Fleet (2008) mengatakan jenis-jenis kapang yang menghasilkan toksin antara lain adalah $A$. flavus, $A$. parasiticus, dan A. nigersedangkan menurut Maryam (2007) kapang toksigenik yaitu Aspergillus sp. dan Fusarium sp.

Untuk melihat hubungan antara jenis kapang yang tumbuh dengan kadar garam dan $a_{w}$ ikan pindang, data yang diperoleh dirangkum kembali dalam Tabel 7.

Data dalam penelitian ini menunjukkan bahwa tidak ada hubungan antara jenis kapang yang diisolasi dari

Tabel 7. Hubungan jenis kapang dengan kadar garam dan aktivitas air pada ikan pindang Table 7. Relationship between fungal species with salt content and water activity of boiled salted fish

\begin{tabular}{|c|c|c|c|}
\hline $\begin{array}{l}\text { Jenis Kapang/ } \\
\text { Fungal Species }\end{array}$ & $\begin{array}{l}\text { Asal Isolat Kapang/ } \\
\text { Origin of fungal isolate }\end{array}$ & $\begin{array}{l}\text { Kadar Garam/ } \\
\text { Salt Content } \\
\quad(\%)\end{array}$ & $\begin{array}{l}\text { Aktivitas Air/ } \\
\text { Water activity }\end{array}$ \\
\hline A. flavus & $\begin{array}{l}\text { Bandeng, Cakalang, Kembung, Salem, Semar, } \\
\text { Tongkol/Milk Fish, Skipjack Tuna, Indian Mackarel, } \\
\text { Rainbow Runner, Moon Fish, Mackarel Tuna }\end{array}$ & $3.80 \pm 2.68$ & $0.96 \pm 0.02$ \\
\hline A. fumigatus & $\begin{array}{l}\text { Bandeng, Cakalang, Layang, Mas, Salem, } \\
\text { Tongkol/Milk Fish, Skipjack Tuna, Indian Scad, Carp } \\
\text { Fish, Rainbow Runner, Mackerel Tuna }\end{array}$ & $4.42 \pm 1.87$ & $0.95 \pm 0.02$ \\
\hline A. niger & $\begin{array}{l}\text { Bandeng, Cakalang, Kembung, Layang, } \\
\text { Tongkol/Milk Fish, Skipjack Tuna, Indian Mackarel, } \\
\text { Indian Scad, Mackerel Tuna }\end{array}$ & $3.81 \pm 1.66$ & $0.96 \pm 0.02$ \\
\hline A. ochraceus & Bandeng/Milk Fish & $3.66 \pm 0.52$ & $0.95 \pm 0.01$ \\
\hline A. sydowii & Salem, Semar/Rainbow Runner, Moon Fish & $3.81 \pm 3.69$ & $0.96 \pm 0.01$ \\
\hline A. terreus & Bandeng, Layang/Milk Fish, Indian Scad & $3.40 \pm 0.88$ & $0.95 \pm 0.01$ \\
\hline A. oryzae & Tongkol/Mackerel Tuna & $2.03 \pm 0.01$ & $0.94 \pm 0.01$ \\
\hline C. allicinum & Tongkol/Mackerel Tuna & $1.48 \pm 0.01$ & $0.97 \pm 0.01$ \\
\hline E. chevalieri & $\begin{array}{l}\text { Bandeng, Semar, Tongkol/Milk Fish, Moon Fish, } \\
\text { Mackerel Tuna }\end{array}$ & $2.52 \pm 1.31$ & $0.97 \pm 0.01$ \\
\hline F. cerealis & Semar, Tongkol/Moon Fish, Mackerel Tuna & $2.00 \pm 0.28$ & $0.97 \pm 0.02$ \\
\hline F. graminearum & Salem/Rainbow Runner & $6.4 \pm 0.01$ & $0.95 \pm 0.01$ \\
\hline Loweporus sp. & Mas, Layang/Carp Fish, Indian Scad & $4.67 \pm 3.72$ & $0.96 \pm 0.02$ \\
\hline P. chermesinum & $\begin{array}{l}\text { Bandeng, Cakalang, Layang, Mas, Salem, } \\
\text { Tongkol/Milk Fish, Skipjack Tuna, Indian Scad, Carp } \\
\text { Fish, Rainbow Runner, Mackerel Tuna }\end{array}$ & $4.28 \pm 1.98$ & $0.96 \pm 0.02$ \\
\hline P. chrysogenum & Bandeng/Milk Fish & $4.47 \pm 0.01$ & $0.93 \pm 0.01$ \\
\hline P. citrinum & $\begin{array}{l}\text { Bandeng, Kembung, Layang, Salem, Semar, } \\
\text { Tongkol/Milk Fish, Indian Mackarel, Indian Scad, } \\
\text { Rainbow Runner, Moon Fish, Mackerel Tuna }\end{array}$ & $3.27 \pm 1.82$ & $0.96 \pm 0.02$ \\
\hline S. racemosum & Layang, Tongkol/Indian Scad, Mackerel Tuna & $2.31 \pm 0.92$ & $0.96 \pm 0.02$ \\
\hline
\end{tabular}


ikan pindang dengan jenis ikan atau nilai $\mathrm{a}_{\mathrm{w}}$ (Tabel 7). Hal ini serupa dengan yang dilaporkan Wheeler et al. (1986) bahwa jenis kapang yang diisolasi dari ikan asin tidak ada hubungan antara jenis ikan atau nilai aw. Selain itu, pada penelitian ini tidak ditemukan adanya hubungan antara jenis kapang yang tumbuh pada ikan pindang dengan kadar garam (Tabel 7). Hal ini kemungkinan terjadi karena semua sampel ikan pindang mempunyai kadar garam $<10 \%$, sehingga hampir semua jenis kapang bisa tumbuh. Atapattu dan Samarajeewa (1990) melaporkan bahwa beberapa jenis kapang dapat tumbuh pada kadar garam $<30 \%$, seperti Aureobasidium spp dan Gleomastix spp, $A$. flavus, A. fumigatus, A. niger, C.herbarum, P.chalybeum dan P.expansum. Jenis kapang yang diisolasi dari ikan pindang dengan kadar garam $1 \%$ yaitu $A$. flavus, $A$. niger, $A$. ochraceus, P.crysogenum dan Rhyzopus oryzae (Indriati, 2008). Sedangkan menurut Prakash, Jeyasanta, Carol, dan Patterson (2011), A. niger dan A. flavus masih dapat tumbuh pada kadar garam $18 \%$, A. fumigatus dan Penicillium sp. pada kadar garam $<14 \%$, A. oryzae, A. nidulan dan Mucor sp. pada kadar garam $<10 \%$.

\section{KESIMPULAN}

Hasil isolasi dan identifikasi kapang secara morfologi dan moleuler dari ikan pindang diperoleh 119 isolat kapang, yang terdiri dari 7 genus dan 16 spesies, yaitu $A$. flavus, $A$. fumigatus, $A$. niger, $A$. ochraceus, A. oryzae, A. sydowii, A. terreus, C. allicinum, E. chevalieri, F. graminearum, F. cerealis, Loweporus sp., P. citrinum, P. chermesinum, $P$. chrysogenum, dan $S$. racemosum. Terdapat enam jenis kapang yang dominan yaitu $P$. chermesinum diikuti oleh $P$. citrinum , $A$. fumigatus, $A$. flavus, $A$. niger, dan $E$. chevalieri.

\section{DAFTAR PUSTAKA}

Abarca, M. L., Bragulat, M. R., Castella, G., \& Cabanes, F. J. (1994). Ochratoxin A Production by Strain of Aspergillusniger var. niger. Appl. Environ. Microbiol., 60, 2650-2652.

Adebajo, L.O., \& Diyaolu, S. A. (2003). Mycology and Spoilage of Retail Cashew Nuts. Afr. J. Biotechnol, 2, 369-373.

Agustin, W. (2016). Inventarisasi dan Identifikasi Kapang pada Produk Ikan Asin. Skripsi. Universitas Nasional Jakarta, $81 \mathrm{pp}$.

Anonim. (2012). Kontribusi Olahan Pindang Terbesar Dibandingkan Olahan Lainnya. www.pikiranrakyat.com/ekonomi/2012/06/26/193646/kontribusiolahan-pindang-terbesar-dibandingkan-olahanlainnya. Diakses pada tanggal 7 Februari 2018.
Anonim. (2016). Potensi Ikan Pindang di Indonesia. https ://www.kompasiana.com /mustofhaa /potensi-ikanpindang-di- Indonesia_56bc4d0782afbd58075aabbe. Diakses pada tanggal 6 Februari 2018.

Ariyani, F. \& Yennie, Y. (2008). Pengawetan Pindang Ikan Layang (Decapterus russelli) Menggunakan Kitosan. Jurnal Pasca panen dan Bioteknologi Kelautan dan Perikanan, 3 (2), 139-146.

Atapattu, R. \& Samarajeewa, U.(1990). Fungi associated with dried fish in Sri-Lanka. Mycopathologia, 111(1),55-59.

Badan Standarisasi Nasional (BSN).(1991). Penentuan Kadar Garam pada produk perikanan. SNI 01-23591991.

Badan Standarisasi Nasional (BSN). (2009). SNI 2332.7 : 2009. Cara Uji Mikrobiologi- Bagian 7: Perhitungan Kapang \& Khamir Pada Produk Perikanan.

Chandra, A. N. \& Setiawan, A. H. (2013). Analisis Propsek dan Perkembangan Usaha Industri Bandeng Presto Di Kota Semarang. Diponogoro Journal of Economics, 2(1), 1-11.

Cole, J. R. (1981). Fungal Tremorgens. J.Food Prot, 44, 715-722.

Crous, P. W., Schoch, C. L., Hyde, K. D., Wood, A. R., Gueidan, C., de Hoog, G. S., \& Groenewald, J. Z. (2009). Phylogenetic Lineages in The Capnodiales. Journal Studies in Mycology, 64, 17-47.

De Hoog, G. S., Guarro, J. Gene, J. \& Figucras, M.J. (2000). Atlas of Clinical Fungi, $2^{\text {nd }}$ ed Utreccht: Centraal bureau voor Schimmel cultures.

Dorner, J. W., Cole, R. J. \& Hill, R .A. (1984).Tremorgenic mycotoxin produced by $\mathrm{A}$. fumigatus and $P$. crustosum isolated from molded corn implicated in a natural intoxication of cattle. J. Agric. Food Chem, 42, 15161618.

Frisvad, J. C., Thrane, U., Samson, R. A., \& Pitt, J. I. (2006). Important Mycotoxins and fungi wich Produced Them. Advances in Food Mycology - Advances in Experimental Medicine and Biology, Vol571. Eds. A.D. Hocking, J.I. Pitt, R.A. Samson \& U.Thrane.Berlin: Springer - Verla gpp 3-31.

Frisvad, J. C., Smedgaar, J., Samson, R. A., Larsen, T. O., \& Thrane, U. (2007). Fumonisin B2 Production by A. niger. J. Agric. Food Chem, 55, 9727-9732.

Gandjar, I., Samson, R.A., \& Vermeulen, K.V.D.T. (1999). Pengenalan Kapang Tropik Umum. Yayasan Obor Indonesia, Jakarta,-

Hermana, I \& Indriati, N. (2012). Kajian Mikrobiologi Abon Ikan Marlin (Istiophorus sp.) Selama Penyimpanan Suhu Kamar. Prosiding Seminar Nasional MPHPI, Malang 2012, 87-92.

Hermana, I., Hidayah, I., \& Indriati, N. (2016). Kondisi Sanitasi Di Tempat Pengolahan Pindang di Palabuhan Ratu. Prosiding Seminar Nasional Perikanan Kelautan dan Perikanan.

Ibrahim, R. (1986). Production and Storage of Salt Boiled Fish (Pindang) Using Atlantic Mackerel (Scomber scombus). Thesis. Loughborough University Institutional Reposity. 
Indriati, N.,Supriadi, M. W. \& Salasa, F.F. (2008). Isolasi dan Identifikasi Jamur Pada Pindang Tongkol (Euthynnus Affinis). Jurnal Pascapanen dan Bioteknologi Kelautan dan Perikanan, 3(1), 11-20.

Indriati, N., Priyanto, N., Triwibowo, R. (2010). Penggunaan Dichloran Rose Bengal Chloramphenicol Agar (DRBC) Sebagai Media Tumbuh Kapang Pada Produk Perikanan. Jurnal Pasca panen dan Bioteknologi Kelautan dan Perikanan, 5(2), 117-121.

Indriati, N. \& Murniyati. (2012). Kajian Mikrobiologi Pindang Ikan Tongkol Komersil Selama Penyimpanan. Prosiding Seminar Nasional Tahunan IX. Hasil Penelitian Perikanan dan Kelautan.

Irianto, H. E. \& Pratiwi, Y. S. (2009). Chemical and Organoleptical Changes in Pindang Cue During Storage Ambient and Chill Temperatures. Journal of Marine and Fisheries Postharvest and Biotechnology - Special Edition in Conjunction with World Ocean Conference, 4, 67-72.

Kurtzman, C. P., Smiley, M. J., Robnet, C. J. \& Wicklow, D. T. (1986). DNA Relatedness Among Wild and Domesticated Species in The Aspergillus flavus Group. J.Mycologia, 78 (6).

Maryam, R. (2007). Metode Deteksi Mikotoksin. J. Mikot. Ked.Indon, 7(1-2),12-24.

Nasution, R. (2003). Teknik Sampling. USU digital library.http://library.usu.ac.id /download/fkm/fkm : rozaini.pdf. Diakses pada tanggal 29 Januari 2018.

O’Donnel, S., Logan, C.J., Clayton, N.S. (2012). Specializations of Birds That Attentd Army Ant Raids : An Ecological Approach to Cognitive and Behavioral Studies. Journal Behavioral Process, 91, 267-274.

Pitt, I. J. \& Hocking, A. D. (2009). Fungi and Food Spoilage. 3rd Ed. Springer, New York: 519 pp.

Prakash, S., Jeyasanta, I., Carol, R. \& Patterson, J. (2011). Microbial Quality of Salted and Sun Dried Sea Foods of Tuticorin Dry Fish Market Southeast Coast of India. International Journal of Microbiological Research, 2(2), 188-195.

Rahayu, W. P, \& Nurwitri, C. C. (2012). Mikrobiologi Pangan. IPB Press, Bogor.

Rahayu, E. S., Sarjono, \& Samson, R. A. (2014). Jamur Benang (Mold) pada Bahan Pangan. P.T. Kanisius Yogyakarta, $284 \mathrm{pp}$.
Rahayu, E. S., Kamil, R. Z., Damara, Y., \& Sidar, A. (2016). The Occurance of Toxigenic Fungi in Indonesian Dried Food Product. International Commission on Food Mycologi (ICFM) Freising Germany. $38 \mathrm{pp}$

Rahmadi, \& Fleet. G. H. (2008). The Occurrence of Mycotoxygenic Fungi in Cocoa Beans from Indonesia and Queensland, Australia. Proceeding of International Seminar on Food Science, University of Soegiyopranata, Semarang, Indonesia. 1-18.

Samson, R. A., Visagie, C. M., Houbraken, J., Hong, S. B., Hubka, V., Klaassen, C. H. W., Perrone, G., Seifert, K. A., Susca, A., Tanney, J. B., Varga, J., Kocsube, S., Szigeti, G., Yaguchi, T \& Frisvad, J. C. (2014). Phylogeny, Iden tification and Nomenclature of The Genus Aspergillus. Journal Studies in Mycology, 78, 141-173.

Santoso, I., Sari, G. R. D., \& Sembiring, N. D. (1999). Xerophilic Moulds Isolated From Salted and Unsalted Dried Fish From Traditional Markets in Jakarta. Indonesian Food and Nutrition Progress, 6(2), 5558.

Schoch, C. L., Seifert, K. A., Huhndrof, S., Robert, V., Spouge, J. L., Levesque, C. A., Chen, W., \& Fungal Barcoding Consortium. (2012). Nuclear Ribosomal Internal Transcribed Spacer (ITS) Region as a Universal DNA Barcode Marker for Fungi. Journal PNAS, 109(16), 6421-6246.

Seila, N. I. (2014). Determination of fungi and factors associated with their growth on sun dried Rastrine obolaargentea in Gucha South, Kisiicounty, Kenya. Thesis. Kenyatta University,

Susilowati, A. \& Listyawati, S. (2001). Keanekaragaman Jenis Mikroorganisme Sumber Kontaminasi Kultur in Vitro Sub-Lab Biologi Laboratorium MIPA Pusat UNS. Jurnal Biodiversitas II, 110-114.

Thaheer, H., Hasibuan, S., \& Mumpuni, F. S. (2015). Model Resiko Keamanan Pangan Produk Pindang Pada UMKM Pengolahan Ikan Rakyat. Jurnal Pasti, 9 (3), 275-285.

Wheeler, K. A., Hocking, A. D., Pitt, J. I., \& Anggawati, A. M. (1986). Fungi associated with Indonesian dried fish. Food Microbiology, 3, 351-357.

Yulneri, W. \& Noverita. (2014). Penuntun Praktikum Mikrobiologi. Universitas Nasional, Jakarta. 